\title{
Obtención y purificación de IgY dirigidas contra la lectina de Salvia bogotensis
}

\author{
Paola Barroso, Hansen Murcia, Nohora Vega, Gerardo Pérez \\ Laboratorio de Bioquímica, Departamento de Química, Universidad Nacional de Colombia, \\ Bogotá, D.C., Colombia.
}

Introducción. Las inmunoglobulinas presentes en la yema de huevo de gallina ( $\lg Y)$ han sido ampliamente utilizadas en inmunología, bioquímica, biotecnología y salud humana y animal. Aunque presentan una serie de ventajas frente a las lgG de mamíferos, su aislamiento requiere, por una parte, la eliminación de los lípidos presentes en la yema del huevo sin alterar su funcionalidad y, por otra, la utilización de metodologías de purificación que permitan una recuperación tal que haga factible su empleo como herramientas de detección y purificación a una escala significativa.

Objetivo. Dado el interés que presenta el antígeno Tn como marcador tumoral en muchos tipos de cáncer, y la capacidad que tiene la lectina aislada de semillas de Salvia bogotensis para reconocer específicamente este antígeno, se adelantó el presente trabajo con la meta de disponer de $\lg Y$ anti-lectina para emplearla en estudios inmunohistoquímicos y de biología celular.

Materiales y métodos. Se produjo $\lg Y$ anti-lectina inmunizando gallinas con lectina de $S$. bogotensis y se evaluó la respuesta inmune en función de la dosis y del tiempo; se ensayaron varios métodos de remoción de lípidos y de extracción y se compararon los rendimientos y la pureza de lgY obtenidas con varios métodos de purificación.

Resultados. El mejor método de delipidación y extracción de lgY requiere dilución con agua, acidificación del extracto y precipitación con $\left(\mathrm{NH}_{4}\right)_{2} \mathrm{SO}_{4} 60 \% \mathrm{~s}$, recuperándose 43,35 mg de proteína/yema. La cromatografía tiofílica permite obtener las IgY puras en buena cantidad (10,4 mg/yema), preservando la funcionalidad y características de estos anticuerpos.

Conclusión. Se establecieron las mejores condiciones para extraer y purificar lgY funcionales dirigidas contra la lectina de $S$. bogotensis.

Palabras clave: Lamiaceae, inmunoglobulinas Y, Salvia, lectina, purificación, antígeno Tn.

\section{Purification of IgY against Salvia bogotensis lectin}

Introduction. Egg yolk immunoglobulins ( $\lg Y)$ have been extensively used in immunology, biochemistry, and biotechnology in studies of human and animal health. However, their use requires two preparatory steps: first, the egg yolk lipids must be removed without impairing the immunoglobin functional properties, and second, the isolation methods must allow high recoveries for further use as detection and purification tools.

Objective. Because Tn antigen presence serves as a tumoral marker and because S. bogotensis lectin's can specifically recognize this antigen, the current study aims at making available an anti-lectin IgY. This tool will be useful in histochemical and cellular studies involving transformed cells.

Materials and methods. Anti-lectin $\lg Y$ was produced by immunization of hens with $S$. bogotensis lectin, and the effect of antigen dose on $\lg Y$ levels was assesed. Several methods for lipid removal, IgY extraction and purification were assayed, and yields and purity of $\lg Y s$ were established for each method.

Results. The best delipidation and extraction method included yolk dilution with water under acidic conditions and $\left(\mathrm{NH}_{4}\right)_{2} \mathrm{SO}_{4} 60 \%$ s precipitation from which $43 \mathrm{mg}$ protein/yolk were recovered. Among the chromatographic methods, thiophilic chromatography permitted the 
recovery of a substantial quantity of pure $\lg Y(10.4 \mathrm{mg} \lg /$ /yolk). With this method, the function and characteristics of $\lg Y$ were preserved.

Conclusion. The best conditions for anti-S. bogotensis functional IgY extraction and purification were established.

Key words: Lamiaceae, immunoglobulin Y, Salvia bogotensis, lectin, purification, Tn antigen.

Las inmunoglobulinas presentes en la yema de huevo de gallinas (IgY) son una alternativa muy interesante como herramientas en multitud de estudios de inmunología, bioquímica, biotecnología, salud humana y animal. Ejemplos recientes de su variada utilización son la producción de fragmentos Fab' para evitar reacciones alérgicas a proteínas de huevo (1), para producción de anticuerpos contra antígeno nuclear de células en proliferación (PCNA) (2), así como contra la timidín cinasa humana (3), un trisacárido de galactosa que actúa como antígeno presente en células endoteliales de cerdo (4), y contra el virus de Sendai (5) o algunos venenos de serpiente (6).

Las propiedades fisicoquímicas y la relación evolutiva de estos anticuerpos con las IgG han sido objeto de varias revisiones recientes (7-9); algunas características fisicoquímicas son diferentes a las de lgG, ya que bajo condiciones reductoras no requieren de agentes desnaturalizantes para disociarse en dos cadenas: una liviana (L) con un PM de 20 a $25 \mathrm{kd}$ y una pesada $(\mathrm{H})$ con PM de 65 a $70 \mathrm{kd}$ y, además, se agregan en condiciones de fuerza iónica alta $(1,5$ $\mathrm{M} \mathrm{NaCl}$ ) y su $\mathrm{pl}$ es menor en una unidad de $\mathrm{pH}$ que el de lgG.

Este tipo de inmunoglobulina es el único presente en cantidades significativas en la yema del huevo; estas proteínas son transportadas desde el suero durante la maduración de la yema en el oviducto por un mecanismo similar a la transferencia placentaria que ocurre en mamíferos (10). Ello resulta en mayores concentraciones de $\lg Y$ en la yema que en el suero; diferentes determinaciones

\footnotetext{
Correspondencia:

Gerardo Pérez, Laboratorio de Bioquímica, Departamento de Química, Universidad Nacional de Colombia, Bogotá, Colombia.

Teléfono: $57-1-3165000$ ext 14465/14470

Fax: 57-1-3165220

jrperezg@unal.edu.co
}

Recibido: 18/05/05; aceptado: 26/05/05 arrojan valores hasta de 15 a $25 \mathrm{mg}$ de inmunoglobulinas por $\mathrm{ml}$ de yema en gallinas hiperinmunizadas (11) y, dependiendo del método de aislamiento, se pueden recuperar entre 3 y 5 $\mathrm{mg}$ de anticuerpo/ml de yema (12), por lo que el método empleado en su purificación es crítico para lograr buenos rendimientos.

Estas proteínas presentan una serie de ventajas frente a las IgG de mamíferos debido a diferencias de comportamiento en varios aspectos de la respuesta inmune, como son las siguientes: a diferencia de las IgG de mamífero, funcionalmente las lgY no interactúan con factores reumatoideos (13), de tal manera que la probabilidad de dar falsos positivos en ensayos inmunoquímicos disminuye; al contrario de lo que ocurre con la $\lg G$ de mamíferos, las $\lg Y$ no se unen a la proteína $A$ estafilocócica (14), ni a la proteína G, ni al sistema de complemento humano (15). Estas diferencias, sumadas a la distancia evolutiva existente que resulta en una mayor inmunogenicidad de proteínas de mamíferos inyectadas en aves $(2,11)$ y a las enormes cantidades de IgY producidas por la gallina en su período de postura (150-225 $\mathrm{mg} / \mathrm{yema}$ ), han despertado mucho interés por su utilización.Sin embargo, sus aplicaciones se han visto restringidas por la presencia de los lípidos, que constituyen $50 \%$ de la yema, la cual posee un alto contenido de colesterol y fosfolípidos dispersados en vitelinas y otras fosfolipoproteínas de baja densidad. La necesidad de eliminar estos lípidos para recuperar eficientemente las lgY ya se reconoció en trabajos pioneros (16). Por otra parte, su purificación se ha ensayado con una variedad de técnicas bioquímicas, con resultados poco alentadores en algunos casos, debido probablemente al bajo contenido (1\%) de $\lg Y$ policlonales específicos contra un antígeno dado. El interés de desarrollar métodos de purificación eficientes de $\lg Y$ se ve reforzado porque la preparación de $A b$ monoclonales de gallina contra algunos antígenos es difícil y parece poco práctica (7). 
Entre los distintos tipos de carbohidratos reconocidos por gran diversidad de lectinas presentes tanto en plantas como en animales, se encuentran los antígenos $\mathrm{T}$ y $\mathrm{Tn}$ localizados en glicoproteínas de la membrana celular. La exposición del antígeno Tn en eritrocitos ocasiona el síndrome Tn, o síndrome de poliaglutinabilidad, que es un trastorno caracterizado por la presencia de residuos de $\mathrm{N}$-acetilgalactosamina (GalNAc) en la superficie de la célula roja que, normalmente, se encuentran enmascarados y unidos a Ser/Thr en las sialoglicoproteínas de membrana $(17,18)$. Los antígenos T y Tn también se han encontrado asociados a carcinomas, expuestos en la membrana externa de células tumorales comunes y en metástasis $(19,20)$; la proporción relativa de estos antígenos en las células está estrechamente relacionada con la agresividad con la que evoluciona el tejido canceroso (20).

Considerando lo anterior, y dado el interés de nuestro, Grupo de Investigación en Proteínas (GRIP), en desarrollar herramientas que combinadas con las lectinas permitan la detección del antígeno Tn en células tumorales, se ensayó la producción de IgY contra la lectina de Salvia bogotensis (LSB); se evaluaron los procedimientos de remoción de lípidos de la yema de huevos de gallinas inmunizadas, y se ensayaron los procedimientos de purificación para obtener buenos rendimientos de $\lg Y$ funcionales, capaces de reconocer el antígeno Tn. Los resultados obtenidos se describen en el presente trabajo.

\section{Materiales y métodos \\ Inmunización}

Los procedimientos en animales se ajustaron al protocolo para uso de animales del INS y el proyecto de investigación del cual hace parte este trabajo fue avalado por el Comité de Ética de la División de Investigaciones de la Universidad Nacional.

Con la lectina de $S$. bogotensis purificada según Vega (21) se prepararon soluciones de $100 \mu \mathrm{g} /$ $\mathrm{ml}, 400 \mu \mathrm{g} / \mathrm{ml}$ y $1000 \mu \mathrm{g} / \mathrm{ml}$ en PBS (fosfatos 20 $\mathrm{mM}, \mathrm{NaCl} 150 \mathrm{mM}$ ) pH 7,2 . A $1 \mathrm{ml}$ de adyuvante de Freund se agregó gota a gota $1 \mathrm{ml}$ de estas soluciones con agitación vigorosa para obtener buena emulsificación; para el primer reto se usó adyuvante completo y para los refuerzos, adyuvante incompleto. Un $\mathrm{ml}$ de la emulsión se aplicó en dos sitios del músculo pectoral de gallinas de raza High-Line en edad de plena postura (20 semanas) mantenidas en jaulas individuales con agua y alimento ad libitum. Se organizaron cuatro grupos de tres animales cada uno, de los cuales el primero correspondió al grupo control.

El esquema de inmunización fue similar al descrito por Gassman et al. (2), empleando dosis de $50 \mathrm{y}$ $200 \mu \mathrm{g}$ de LSB por inoculación a los días 0,10 , 20 y 29 y dosis de $500 \mu \mathrm{g}$ de LSB por inoculación a los días 0 y 20 para un total de 200, 800 y 1000 $\mu \mathrm{g} \mathrm{LSB} / g a l l i n a$, respectivamente. Los huevos se recogieron desde el día 9 hasta el día 90; cada huevo se marcó con el número de la gallina correspondiente y la fecha de recolección. Los huevos se almacenaron a $4^{\circ} \mathrm{C}$ hasta su procesamiento. Se llevó un registro de postura minucioso para cada gallina.

\section{Remoción de lípidos y extracción de lg $Y$}

Sin romper el vitelio, las yemas fueron separadas cuidadosamente de las claras y se lavaron con un pequeño volumen de $\mathrm{H}_{2} \mathrm{O}$ destilada, se secaron sobre papel de filtro y se midieron los volúmenes de cada una.

Se compararon distintos métodos de delipidación y extracción de lgY con ensayos preliminares en pequeña escala (1 a 2 yemas), para establecer los rendimientos de proteína luego de la deslipidación y de la precipitación. Se ensayaron los métodos de Polson et al. (12) y Jensenius y Koch (22), que utilizan dilución con buffer y precipitación con PEG 8000 al 3,5\% o 4,4\%, respectivamente; el método de Jensenius et al. (16) precipitando con sulfato de dextrano y $\mathrm{CaCl}_{2}$; el método de Akita y Nakai (23) diluyendo con agua sin acidificar y dos precipitaciones al $19 \%$ y $14 \%$ con $\mathrm{Na}_{2} \mathrm{SO}_{4}$, y el método de Akita y Nakai (24) diluyendo con agua acidificada a pH 5,0 y precipitación con $\left(\mathrm{NH}_{4}\right)_{2} \mathrm{SO}_{4}$ al $60 \%$ s. Para determinar la heterogeneidad de los extractos se realizó electroforesis en geles de poliacrilamida (PAGE-SDS) comparando alícuotas tomadas después de la delipidación de las yemas y de la 
muestra final después de cada precipitación. La actividad de las fracciones después del paso de deslipidación y del paso de precipitación se determinó por ensayos de ELISA.

De acuerdo con los resultados obtenidos, se utilizó uno de los siguientes métodos para la extracción de las IgY a mayor escala. Se escogieron yemas de huevos de fechas cercanas a los títulos más altos (dosis de $200 \mu \mathrm{g}$ en la inmunización). Para cada experimento se utilizaron 8 yemas $(13 \mathrm{ml} /$ yema). Se llevaron a un volumen final de 1.040 $\mathrm{ml}$ con $936 \mathrm{ml}$ de agua destilada (dilución 1:10) y se extrajeron según la metodología que emplea dilución con agua sin acidificación y precipitación con $\mathrm{Na}_{2} \mathrm{SO}_{4}$ (23), o dilución con agua con acidificación y precipitación con $\left(\mathrm{NH}_{4}\right)_{2} \mathrm{SO}_{4}(24)$; los volúmenes del extracto final fueron de $43 \mathrm{ml}$ (1,28 mg proteína/ml) y de $40 \mathrm{ml}$ (0,9 mg proteína/ $\mathrm{ml})$, respectivamente. El título en cada paso se determinó por ELISA. Se tomó como título la máxima dilución a la cual aún se apreciaba actividad. Como valor mínimo de actividad se tomó tres veces el valor de absorbancia del blanco $(0,097 \mathrm{AU})$.

\section{Determinación de proteína}

La cantidad de proteína en los extractos se cuantificó por el método de Bradford (25) utilizando un micrométodo desarrollado en el laboratorio. Los ensayos se realizaron en placas de 96 pozos, en los que se hizo una curva de calibración por duplicado $(2,5,10,15$ y $20 \mu$ l de solución) con BSA $(0,5$ a $0,7 \mathrm{mg} / \mathrm{ml})$. Tanto las muestras como el patrón de BSA se llevaron a un volumen de 20 $\mu \mathrm{l}$ con PBS pH 7,3 y se agregaron $200 \mu \mathrm{l}$ del reactivo de Bradford. Se incubó durante 15 minutos a temperatura ambiente y se leyó a 595 $\mathrm{nm}$ en un lector de microplaca BioRad Model 550. A partir de la curva de calibración se determinó la cantidad de proteína por interpolación.

Las muestras de IgY purificadas se cuantificaron por el método del ácido bicinconínico (BCA) (26) empleando una curva de calibración similar a la descrita. A cada pozo se agregaron $100 \mu \mathrm{l}$ de buffer carbonato $\mathrm{pH} 11,4\left(\mathrm{Na}_{2} \mathrm{CO}_{3} 0,25 \mathrm{M}, \mathrm{NaHCO}_{3} 0,1\right.$ M) y $100 \mu \mathrm{l}$ de reactivo preparado así: a una solución de BCA al $1 \%$ en agua destilada se adicionaron $4 \mu \mathrm{l}$ de solución de $\mathrm{Na}_{2} \mathrm{SO}_{4}$ al $2 \%$ en agua por cada $100 \mu$ l de solución de BCA. A cada pozo se agregó la solución a cuantificar $(20 \mu \mathrm{l})$. Se dejó incubar durante media hora a $37^{\circ} \mathrm{C}$ y se leyó a $540 \mathrm{~nm}$.

\section{Ensayos de ELISA}

La presencia de IgY específicas para LSB en las yemas durante el curso de la inmunización se estableció sensibilizando las placas con las inmunoglobulinas deslipidadas y parcialmente fraccionadas según Polson et al.(12); las determinaciones se hicieron sobre soluciones cuya concentración de proteína fuera similar para evitar errores debidos a diferencias de recuperación de las fracciones. La incubación en tampón de carbonatos $0,1 \mathrm{M} \mathrm{pH}$ 9,6 se hizo durante 3 horas a $37^{\circ} \mathrm{C}$ y durante la noche a $4^{\circ} \mathrm{C}$, se bloqueó con PBS-BSA $(1,3 \%)$ durante 1 hora a $37^{\circ} \mathrm{C}$, se sembraron $100 \mu \mathrm{l}$ de LSB $(77 \mu \mathrm{g} / \mathrm{ml})$ incubando durante 1 hora a $37^{\circ} \mathrm{C}$ y, luego, $100 \mu$ ld lgG-antiLSB (generado en conejo) (21) durante 1 hora a $37^{\circ} \mathrm{C}$. Se reveló con $100 \mu \mathrm{l}$ de anti-lgG (generado en cabra,Sigma) marcado con peroxidasa e incubando con ácido 2,2'-azino-bis (3etilbenzotiazoline)-6-sulfónico (ABTS). Se leyó la absorbancia a $405 \mathrm{~nm}$ en un lector de microplaca BioRad Model 550. Entre cada paso se hicieron tres lavados con PBS-Tween 20 al 0,1\%.

Se evaluó la actividad de cada una de las fracciones obtenidas en los ensayos de remoción de lípidos y de los pasos de extracción por dilución

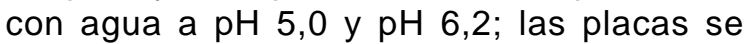
sensibilizaron con LSB $(30 \mu \mathrm{g} / \mathrm{ml})$ y se siguió la metodología descrita por Vega (21) usando como segundo anticuerpo un anti-lgY (generado en cabra, Sigma) y acoplado a peroxidasa, en una dilución de 1/1000 en PBS-suero fetal bovino (SFB) (10\%).

En los ensayos preliminares se emplearon las fracciones deslipidada y final a una concentración de $500 \mu \mathrm{g} / \mathrm{ml}$ en SFB $10 \%$. El título de los diferentes pasos de extracción de lgY se evaluó haciendo diluciones seriadas a partir de una solución de $500 \mu \mathrm{g} / \mathrm{ml}$ para un volumen final de $100 \mu \mathrm{l}$ por pozo en cada dilución.

Para determinar el título durante la purificación se siguió la metodología ya descrita sensibilizando 
con la lectina $(15 \mathrm{ug} / \mathrm{ml})$ disuelta en tampón de $\mathrm{Na}_{2} \mathrm{CO}_{3} 1 \mathrm{M}, \mathrm{pH} 9,6$. Con las fracciones obtenidas en las etapas de purificación del anticuerpo se prepararon soluciones de $0,5 \mathrm{mg} / \mathrm{ml}$ y se realizaron diluciones seriadas a un volumen final de $100 \mu \mathrm{l} /$ pozo. La detección de la interacción se hizo con un Ab secundario acoplado a peroxidasa (anti-lgY gallina, generado en cabra, Sigma).

\section{Purificación $\lg Y$}

Con los extractos finales se ensayó la purificación por diversas cromatografías de columna basadas en diferentes principios de separación.

\section{DEAE-Sephacel}

Se utilizó el método descrito por Baines y Thorpe (27). Del extracto sin acidificar se sembraron 9 $\mathrm{ml}(8,2 \mathrm{mg})$ equilibrados en tampón de fosfatos $70 \mathrm{mM} \mathrm{pH} \mathrm{6,3} \mathrm{sobre} \mathrm{una} \mathrm{columna} \mathrm{de} \mathrm{DEAE-}$ Sephacel $(1,8 \times 6,5 \mathrm{~cm})$. La fracción no retenida se eluyó con tampón de equilibrio y el retenido se eluyó con tampón de fosfatos $\mathrm{pH}$ 6,3- $\mathrm{NaCl} 1 \mathrm{M}$. Las fracciones retenida y no retenida se dializaron contra $\mathrm{NH}_{4} \mathrm{HCO}_{3} 20 \mathrm{mM}$ y se congelaron.

Esta cromatografía se hizo también bajo las siguientes condiciones. Se sembraron $18 \mathrm{ml}(23$ $\mathrm{mg}$ ) de extracto final obtenido por dilución con agua a $\mathrm{pH} 5,0$ y equilibrado en tampón de fosfatos $\mathrm{pH} 6,3$. La fracción no retenida se eluyó con el tampón de equilibrio. Luego se eluyó el retenido a diferentes $\mathrm{pH}$. La primera elución se hizo con tampón de glicina $50 \mathrm{mM}-\mathrm{HCl} \mathrm{pH}$ 2,8 neutralizando cada fracción colectada $(1 \mathrm{ml})$ con $200 \mu \mathrm{l}$ de tampón Tris $200 \mathrm{mM}-\mathrm{HCl} \mathrm{pH} 8,8$, la segunda fracción se eluyó con tampón de fosfatos $50 \mathrm{mM}$ $\mathrm{pH} 7,3$, la tercera fracción con tampón de Tris 50 $\mathrm{mM}-\mathrm{HCl} \mathrm{pH}$ 8,8 y la última fracción con tampón de fosfatos $\mathrm{pH} 6,3-\mathrm{NaCl} 1 \mathrm{M}$. Estas fracciones se dializaron contra $\mathrm{NH}_{4} \mathrm{HCO}_{3} 20 \mathrm{mM}$ y se concentraron por liofilización.

\section{Fenil-sefarosa-4B}

Se empleó el procedimiento descrito por Hassl y Aspöck (28). Se tomaron $4 \mathrm{ml}$ (3,6 mg) del extracto sin acidificar equilibrado en $\mathrm{NaCl} 1 \%$ y se sembraron sobre una columna de fenil-sefarosa 4B $(1 \times 50 \mathrm{~cm})$. La fracción no retenida se eluyó con $\mathrm{NaCl} 1 \%$ y la fracción retenida con agua desionizada. Luego, se lavó la columna con 50 $\mathrm{ml}$ de acetonitrilo (MeCN) al $70 \%(\mathrm{v} / \mathrm{v})$ para eliminar cualquier sustancia que hubiese permanecido retenida en la columna.

\section{Sephacryl S-200}

Se utilizó una columna de Sephacryl S-200 (1x80 $\mathrm{cm})$ sobre la cual se sembraron $3 \mathrm{ml}(2,7 \mathrm{mg}) \mathrm{de}$ extracto sin acidificar. La columna se eluyó con $\mathrm{NaCl} 1 \%$. En otras cromatografías se sembró 1 $\mathrm{ml}$ de la fracción eluida con glicina- $\mathrm{HCl}, \mathrm{pH} 2,8$, proveniente de DEAE-Sephacel $(2,1 \mathrm{mg}) \circ 1 \mathrm{ml}$ de extracto de $\lg \mathrm{Y}$ precipitado con $\left(\mathrm{NH}_{4}\right)_{2} \mathrm{SO}_{4}$ $60 \%$ s (24,5 mg). Se corrió con tampón de fosfatos $20 \mathrm{mM} \mathrm{pH} 7,3-\mathrm{NaCl} 1 \mathrm{M}$. A cada fracción sembrada se agregaron $87 \mathrm{mg}$ de $\mathrm{NaCl}$.

\section{Sephacryl S-500}

Se utilizó una columna de Sephacryl S-500 (1x92 $\mathrm{cm})$ donde se sembró $1 \mathrm{ml}(0,9 \mathrm{mg})$ de extracto sin acidificar. La elución se realizó con $\mathrm{NaCl} 1 \%$.

\section{Cromatografía tiofílica}

Se siguió la técnica de Hansen et al. (29).Se utilizó un soporte de Sefarosa 4B activado con divinilsulfona (DVS) al cual se acopló $\beta$ mercaptoetanol ( $\beta$-MESH) modificando parcialmente el método de Hermanson et al. (30). Se colocaron $2 \mathrm{ml}$ de sefarosa $4 \mathrm{~B}$ lavados con 20 $\mathrm{ml}$ de agua destilada sobre un embudo con placa sinterizada y se eliminó el exceso de agua; el gel se resuspendió en $2 \mathrm{ml}$ de $\mathrm{Na}_{2} \mathrm{CO}_{3} 0,5 \mathrm{M}, \mathrm{pH} 11,0$, y se dejó en agitación suave. Se agregaron después $200 \mu \mathrm{l}$ de DVS, gota a gota en constante agitación durante un lapso de 15 minutos y se dejó ocho horas. Se lavó con abundante agua destilada hasta que el pH del lavado fuese neutro. En este paso el gel se puede emplear para acoplar cualquier ligando de interés o puede ser almacenado para su uso posterior. Para el acople del ligando, en este caso $\beta$-MESH, se tomó el gel activado y se lavó en un embudo con $20 \mathrm{ml}$ de $\mathrm{Na}_{2} \mathrm{CO}_{3} 0,5 \mathrm{M} \mathrm{pH} 11,0$, se eliminó la solución de carbonato en un embudo y se resuspendió en 2 $\mathrm{ml} \mathrm{de} \mathrm{Na}_{2} \mathrm{CO}_{3} 0,5 \mathrm{M}$. Se adicionaron $400 \mu \mathrm{l}$ de $\beta$ $\mathrm{MESH}$ al $99 \%$ y se dejó en agitación permanente durante 18 horas. Se eliminó la solución y se lavó el gel con abundante agua y con $\mathrm{NaCl} 1 \mathrm{M}$. Posteriormente, el soporte (T-gel) se equilibró 
en tampón de fosfatos $50 \mathrm{mM} \mathrm{pH} 7,3-\mathrm{Na}_{2} \mathrm{SO}_{4} 0,5$ M. Se sembraron $3 \mathrm{ml}(2,7 \mathrm{mg})$ de extracto $\sin$ acidificar, al cual se agregaron $71 \mathrm{mg}$ de $\mathrm{Na}_{2} \mathrm{SO}_{4}$ por mililitro de extracto. La elución del no retenido se realizó con el tampón de equilibrio y el retenido se eluyó con tampón de fosfatos $50 \mathrm{mM} \mathrm{pH} \mathrm{7,3.}$ Se realizaron ensayos análogos con extractos acidificados.

Las fracciones provenientes de las diferentes cromatografías se recolectaron y algunas se concentraron en Microsep Omega de $10 \mathrm{kd}$ a 7000 rpm $(5.857 \mathrm{~g})$. Las fracciones de anticuerpo puro se cuantificaron por BCA.

\section{Electroforesis en poliacrilamida (PAGE-SDS)}

La preparación de los geles de poliacrilamida se realizó según Laemmli (31). En cada pozo se sembraron $20 \mu \mathrm{g}$ de proteína más $5 \mu$ l de tampón muestra con reductor ( $\beta$-MESH). Para las electroforesis en condiciones no reductoras se omitió el $\beta$-mercaptoetanol. Se utilizaron geles al $12 \%$ y $8 \%$ (C 2,5\%). Como tampón de corrido se utilizó Tris $25 \mathrm{mM}$-glicina $192 \mathrm{mM}, \mathrm{pH}$ 8,8. La electroforesis se corrió a $150 \mathrm{~V}$ durante hora y media. Luego del corrido, los geles se fijaron y colorearon con solución de Coomassie R 250 durante tres horas.

\section{Dot-blot}

Con los extractos y las fracciones retenidas en la cromatografía tiofílica se realizó un dot blot directo para detectar la presencia de lgY y la interacción de las mismas con la LSB. La metodología para la detección fue la siguiente: en una microplaca $(10 \mu \mathrm{l})$ se realizaron diluciones seriadas de cada uno de los antícuerpos en PBSSFB (10\%) y se sembraron $5 \mu$ por punto sobre la membrana de nitrocelulosa; se dejó una hora a temperatura ambiente. Se bloqueó agregando 20 $\mathrm{ml}$ de PBS-SFB (10\%) y dejando en agitación durante una hora a temperatura ambiente. Luego, se adicionó una dilución 1/1000 de IgG anti-lgY (cabra) acoplado a peroxidasa. Se reveló con una solución de $50 \mathrm{mg}$ de diaminobenzamidina (DAB) en $100 \mathrm{ml}$ de PBS y $10 \mu \mathrm{lde} \mathrm{H}_{2} \mathrm{O}_{2}$ al $30 \%$; la reacción se detuvo con agua desionizada. Entre cada paso se hicieron tres lavados agregando 20 $\mathrm{ml}$ de PBS-Tween $(0,1 \%)$, a excepción del último, en el cual se lavó cinco veces. Entre el segundo y el tercer paso no se realizó el lavado.

El dot-blot para determinar la funcionalidad de las IgY se realizó así: sobre membranas de nitrocelulosa se colocaron $5 \mu \mathrm{l}$ de lectina pura $(0,608 \mathrm{mg} / \mathrm{ml})$ en PBS por punto durante una hora a temperatura ambiente. Se bloqueó agregando $20 \mathrm{ml}$ de PBS-SFB (10\%) durante una hora a temperatura ambiente. Se incubaron las membranas con diluciones de las IgY en PBSSFB $(10 \%)$ durante una hora a temperatura ambiente y 12 horas a $4^{\circ} \mathrm{C}$. Se incubó con una dilución de 1/1000 de lgG anti-lgY-peroxidasa en PBS-SFB (10\%), dejando en agitación durante una hora a temperatura ambiente. Se reveló y lavó siguiendo el procedimiento anterior.

\section{Resultados}

\section{Ensayos de inmunización}

El control de postura mostró una producción de huevos sin caídas apreciables durante los 90 días de la recolección. La producción de lgY, obtenidas según Polson et al. (12) y evaluada por ELISA, se muestra en la figura 1 . Con la dosis más baja de LSB $(50 \mu \mathrm{g})$ se observó un período de máxima producción entre los 26 y los 40 a 45 días, mientras que para 200 y $500 \mu \mathrm{g}$ de antígeno por

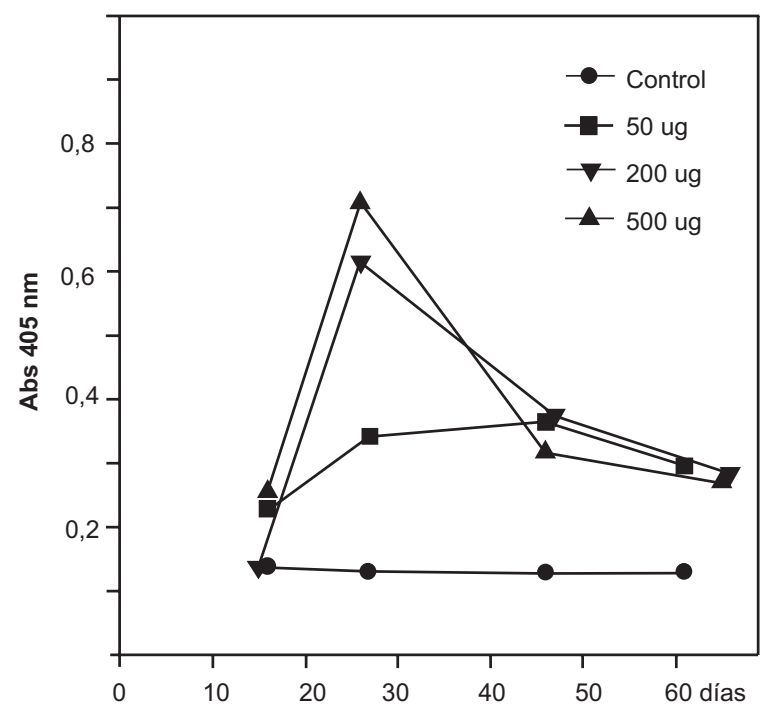

Figura 1. Producción de $\lg Y$ durante el período de la inmunización con diferentes dosis de lectina de Salvia bogotensis. 
inoculación, el pico máximo estuvo alrededor de los 26 días y luego comenzó a declinar, permaneciendo a los 60 días en niveles significativamente mayores que los de los controles.

Los datos de ELISA evidenciaron cantidades apreciables de lgY que se correlacionaron con las dosis de antígeno aplicadas. Las determinaciones de título (yemas de 26 a 27 días) mostraron que las diluciones superiores a 1:200 presentaban por ELISA valores constantes y muy cercanos a los controles con yemas de animales no inmunizados. Un comportamiento similar se observó con yemas de 40 y 65 días, corroborándose así que la respuesta inmune se matenía después de varias semanas del último refuerzo.

\section{Ensayos de deslipidación y extracción}

Una vez realizados los diversos ensayos de remoción de lípidos y precipitación (fracción final) se cuantificó la proteína; los resultados se presentan en el cuadro 1 . Se observa que la delipidación con PEG 8000 al 3,5\% o 4,4\% (12,22) permite recuperar cantidades importantes y similares de proteína con pocos contaminantes como se aprecia en el perfil por PAGE-SDS, particularmente en el caso de la precipitación con PEG al 3,5\% (figura 2, carril 5 ).

Cuando se utiliza la deslipidación con sulfato de dextrano y $\mathrm{CaCl}_{2}$ (16), la cantidad de proteína recuperada en el precipitado final no es muy alta

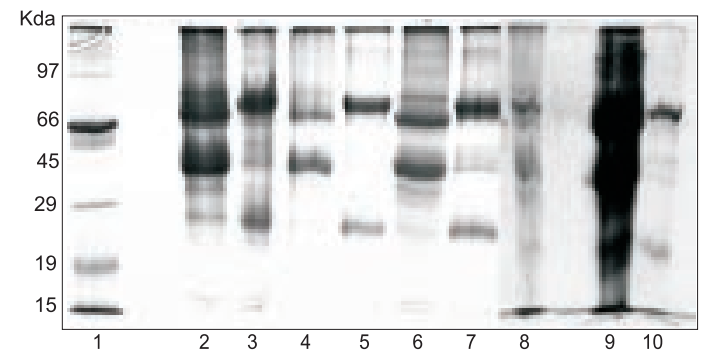

Figura 2. Análisis por PAGE-SDS de las fracciones delipidadas y finales. Carriles 1: patrones de peso molecular; 2: agua deslipidada; 3: agua final; 4: PEG 3,5\% deslipidado; 5: PEG 3,5\% final; 6: PEG 4,4\% deslipidado; 7 : PEG 4,4\% final; 8: dextrano deslipidado; 9: dextrano deslipidado; 10: dextrano final. aunque contiene muy pocos contaminantes cuando se evalúa por PAGE-SDS; sin embargo, al agregar $\mathrm{Na}_{2} \mathrm{SO}_{4}$ para precipitar las proteínas solubles apareció un precipitado blanco difícil de eliminar por diálisis, el cual ocasionó un corrido difuso de las muestras por electroforesis (figura 2, carril 10).

La deslipidación por dilución con agua sin acidificar (23) ocasiona algunos contaminantes en la región de alto peso molecular y en la de 45 a $50 \mathrm{kd}$ que no corresponden a las bandas $\mathrm{H}(70 \mathrm{kd})$ ni $\mathrm{L}$ (25 kd) (figura 2, carril 3; figura 3A, carril 3), y, además, la remoción de los lípidos de la yema es incompleta. Akita y Nakai (24) mostraron que el método de dilución con agua puede optimizarse disminuyendo el pH de aproximadamente 6,2 a $\mathrm{pH} 5,0$ con $\mathrm{HCl} 0,1 \mathrm{M}$; al incubar durante seis horas a pH 5,0 observamos que se removió casi toda la fracción lipídica y se recuperó una gran cantidad de proteína (45 mg/yema); además, la acidificación del extracto permitió eliminar gran cantidad de contaminantes de alto peso molecu$\operatorname{lar}(>70 \mathrm{kd}$ ) (figura 3B, carril 3); en este extracto fueron claramente visibles las bandas correspondientes a las cadenas pesadas y livianas de la IgY, aunque estas últimas presentaron una menor intensidad de tinción con Coomasie R250, lo que corrobora observaciones previas (29).

Las dos precipitaciones al $19 \%$ y $14 \%$ con $\mathrm{Na}_{2} \mathrm{SO}_{4}$ del método sin acidificar (23) se pueden reemplazar por una precipitación con $\left(\mathrm{NH}_{4}\right)_{2} \mathrm{SO}_{4}$ al $60 \% \mathrm{~s}$, haciendo el proceso más rápido y práctico. En la figura 3B (carril 4) se observa que con esta precipitación se eliminaron los contaminantes de mayor peso y se concentraron algunos entre $36 \mathrm{y}$ $45 \mathrm{kd}$; además, se sorteó el problema de las temperaturas bajas a las cuales el $\mathrm{Na}_{2} \mathrm{SO}_{4}$ precipita, mientras que con el $\left(\mathrm{NH}_{4}\right)_{2} \mathrm{SO}_{4}$ se puede trabajar a $0^{\circ} \mathrm{C}$. Por otro lado, la cantidad de contaminantes presentes en el precipitado con $\mathrm{Na}_{2} \mathrm{SO}_{4}$ al $19 \%$ se puede reducir haciendo una segunda precipitación al 14\% (figura 3A, carril 4).

Con la excepción de los tratamientos con sulfato de dextrano, los ensayos de actividad por ELISA de las fracciones de $\lg Y$ deslipidadas y finales (luego de precipitación) mostraron, como era de esperarse, mayor actividad en éstas últimas; los 

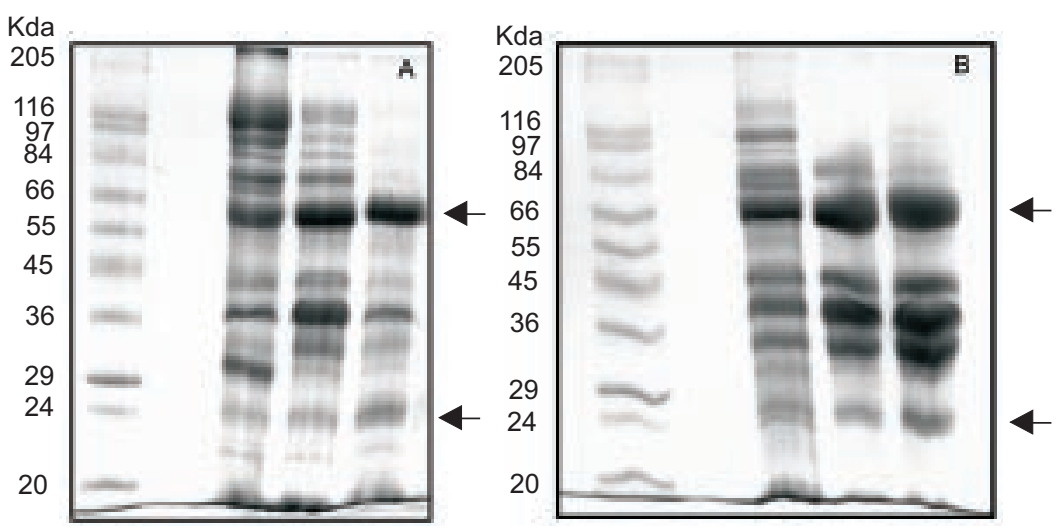

Figura 3. Análisis por PAGE-SDS de (A) fracciones deslipidadas y extraídas con agua a pH 6,2. Carriles 1: patrones de peso molecular; 2: extracto $\mathrm{pH} \mathrm{6,2;} \mathrm{3:}$ deslipidado; 4: precipitación con $\mathrm{Na}_{2} \mathrm{SO}_{4} 19 \%$. (B) fracciones deslipidadas y extraídas con agua a pH 5,0. Carriles 1: patrones de peso molecular; 2: extracto $\mathrm{pH} 5,0$; 3: deslipidado; 4: precipitación con $\left(\mathrm{NH}_{4}\right)_{2} \mathrm{SO}_{4} 60 \%$ s. Las flechas indican la posición de las cadenas $\mathrm{H}$ y $\mathrm{L}$.

Cuadro 1. Cuantificación de proteína en las fracciones provenientes de los ensayos de deslipidación.

\begin{tabular}{lcccc}
\hline Fracción & $\begin{array}{c}\text { Volumen yema } \\
\text { utilizado }(\mathbf{m l})\end{array}$ & $\begin{array}{c}\text { Proteína } \\
(\mathbf{m g})\end{array}$ & $\begin{array}{c}\text { Volumen } \\
\text { yema }(\mathbf{m l})\end{array}$ & $\begin{array}{c}\text { Proteína recuperada } \\
\text { por yema (mg) }\end{array}$ \\
\hline PEG 8000 3,5\% deslipidado & 3,25 & 14,74 & 13 & 12,20 \\
PEG 8000 3,5\% final & & 3,05 & 14,40 \\
PEG 8000 4,4\% deslipidado & 3,25 & 11,98 & 13 & 8,32 \\
PEG 8000 4,4\% final & & 3,60 & & 7,96 \\
Dextrano deslipidado & 3,25 & 11,89 & & \\
Dextrano final & & 2,08 & 13 & 45,35 \\
Agua deslipidada sin acidificar & 3,25 & 27,32 & 13 & \\
Agua final & & 1,99 & 13 \\
Agua pH 5,0 deslipidado & 13,0 & 128,23 & & \\
Agua pH 5,0 final & & 45,35 & & \\
\hline
\end{tabular}

extractos finales con PEG 3,5\% y 4,4\% mostraron actividades menores ( $\mathrm{Abs}_{405}$ 0,300-0,450) que los obtenidos con agua sin acidificar $\left(\mathrm{Abs}_{405} \mathrm{0,650}\right)$, probablemente debido a una desnaturalización parcial de las IgY por la precipitación etanólica.

Como el método de dilución con agua permite la extracción de IgY sin afectar su actividad, se decidió evaluar el anticuerpo en cada etapa de extracción. Los resultados se muestran en la figura 4A para el método sin acidificar y en la figura 4B para el método acidificando a pH 5,0. En los dos procesos se observó que a medida que se progresó en la obtención de las IgY, los valores de título y absorbancia (para una cantidad dada de proteína total) aumentaron, siendo bastante significativos para la fracción reprecipitada con
$\mathrm{Na}_{2} \mathrm{SO}_{4}$ al $14 \%$ (título $1: 64 ; 7,8 \mu \mathrm{g} / \mathrm{ml}$ ) y en la fracción precipitada con $\left(\mathrm{NH}_{4}\right)_{2} \mathrm{SO}_{4}$ al $60 \%$ (título $1: 8 ; 62,5 \mu \mathrm{g} / \mathrm{ml})$. Por otra parte, aunque el extracto acidificado tuvo un menor título, la cantidad de proteína soluble fue mucho mayor, lo cual confirma la excelente recuperación indicada en el cuadro 1.

\section{Ensayos de purificación de $\lg Y$}

Las fracciones recolectadas en las diferentes cromatografías fueron concentradas por liofilización y se cuantificaron por Bradford o por BCA. Las cantidades de proteína en cada fracción se presentan en el cuadro 2, así como las cantidades de proteína total recuperadas.

Del extracto delipidado sin acidificar se tomaron $8,2 \mathrm{mg}$ de proteína y se aplicaron sobre una 
columna de DEAE-Sephacel. En la figura $5 \mathrm{~A}$ se muestra el perfil cromatográfico obtenido, en el cual se encuentra una fracción no retenida muy pequeña y cuatro picos eluídos a alta fuerza iónica; los ensayos de detección mostraron que sólo en los picos II y III están presentes las IgY (figura $6 \mathrm{~A}$, carriles 4 y 5 ). Para tratar de mejorar esta separación, el extracto acidificado $(23 \mathrm{mg}$ de proteína) se eluyó con un gradiente discontinuo de $\mathrm{pH}$ aprovechando la experiencia obtenida en el fraccionamiento de IgG de conejo contra la lectina
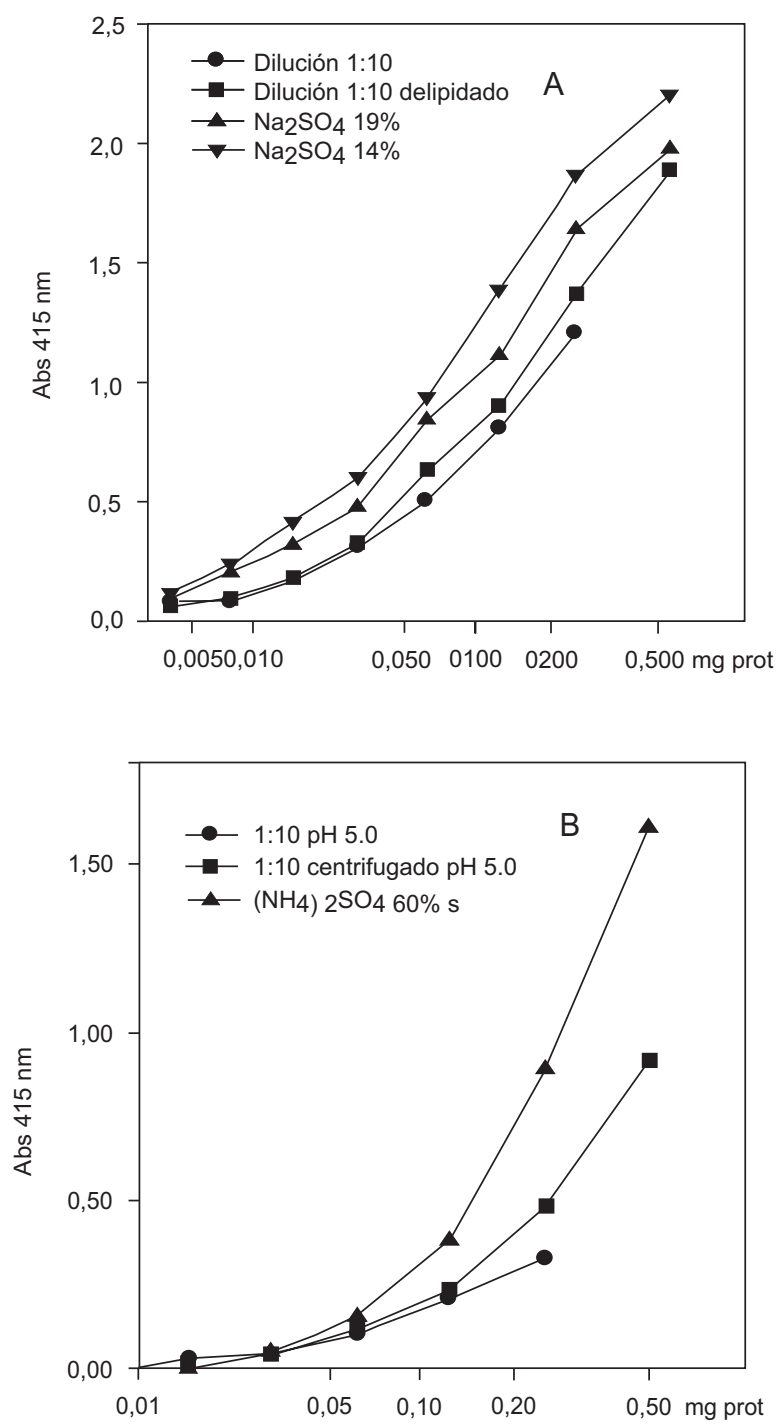

Figura 4. Ensayos de ELISA de las fracciones obtenidas en la deslipidificación de los extractos: $(A)$ fracciones extracto a $\mathrm{pH}$ 6,2; (B) fracciones extracto a $\mathrm{pH} 5,0$.
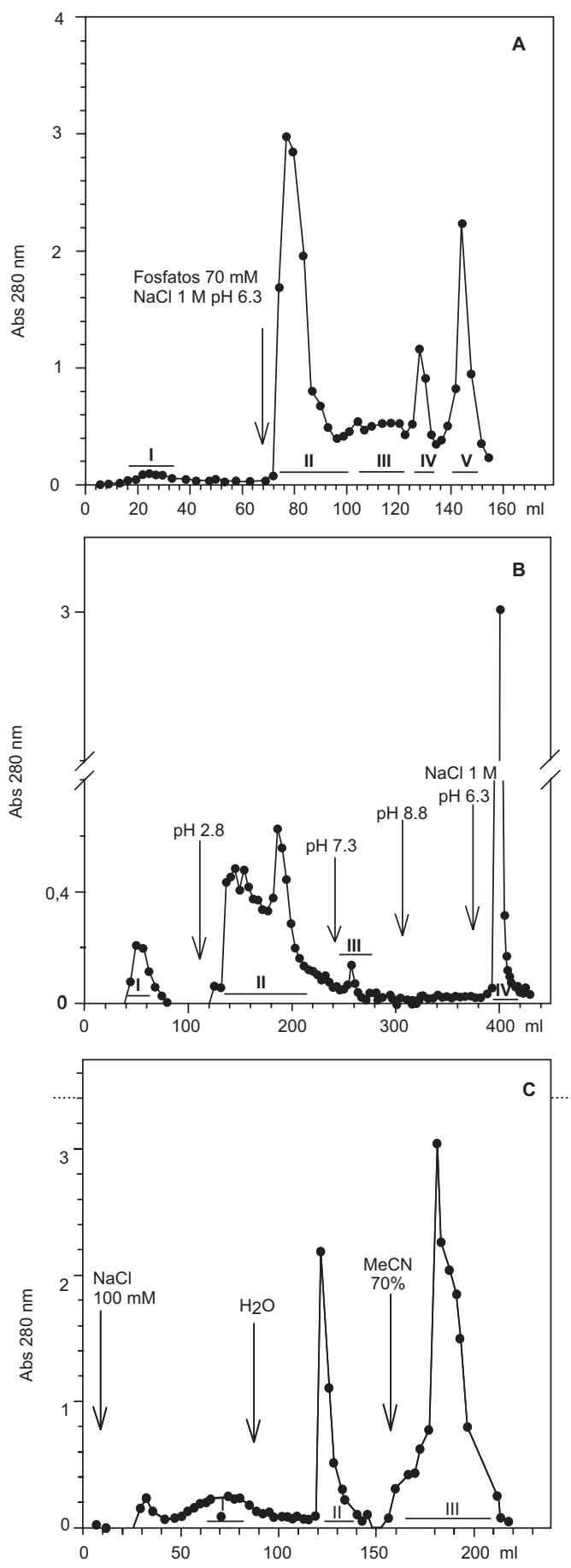

Figura 5. Cromatografías sobre DEAE-Sephacel: (A) extracto sin acidificar; elución por fuerza iónica. (B) extracto acidificado; elución por gradiente discontinuo de $\mathrm{pH}$. (C) cromatografía sobre fenil-Sepharosa 4B del extracto deslipidado sin acidificar. 
Cuadro 2. Cuantificación de proteína en las fracciones provenientes de las cromatografías.

\begin{tabular}{|c|c|c|c|c|}
\hline Fracción & $\begin{array}{l}\text { Proteína en } \\
\text { fracción } \\
(\mathrm{mg})\end{array}$ & $\begin{array}{c}\text { Proteína } \\
\text { recuperada } \\
(\mathrm{mg})\end{array}$ & $\begin{array}{l}\text { Proteína } \\
\text { sembrada } \\
(\mathrm{mg})\end{array}$ & $\begin{array}{c}\text { Recuperación } \\
(\%)\end{array}$ \\
\hline${ }^{*}$ DEAE sin acidificar NR & 0,188 & & & \\
\hline${ }^{*}$ DEAE sin acidificar II & 0,862 & 1,258 & 8,2 & 15,3 \\
\hline${ }^{*}$ DEAE sin acidificar III & 0,208 & & & \\
\hline * DEAE acidificando NR pool & 1,785 & & & \\
\hline ** DEAE acidificando NR máximo & 1,389 & & & \\
\hline ** DEAE eluido 2,8 pool & 5,282 & & & \\
\hline${ }^{* *}$ DEAE eluido $2,8 \mathrm{fr}$ a & 0,300 & 12,272 & 23,0 & 53,0 \\
\hline${ }^{* *}$ DEAE eluido $2,8 \mathrm{fr} b$ & 0,391 & & & \\
\hline${ }^{* *}$ DEAE eluido 2,8 fr c & 0,457 & & & \\
\hline${ }^{* *}$ DEAE eluido $2,8 \mathrm{fr} d$ & 1,086 & & & \\
\hline${ }^{* *}$ DEAE eluido 7,3 & 0,252 & & & \\
\hline ** DEAE eluido $1 \mathrm{M}$ & 1,330 & & & \\
\hline * S-200 & 0,196 & 0,196 & 2,7 & 7 \\
\hline * S-500 I & 0,015 & 0,262 & 0,9 & 28,7 \\
\hline${ }^{*} \mathrm{~S}-500 \quad$ II & 0,248 & & & \\
\hline${ }^{*}$ Fenil-sefarosa NR & 0,017 & 0,429 & 3,6 & 11,7 \\
\hline${ }^{*}$ Fenil-sefarosa- Agua & 0,412 & & & \\
\hline${ }^{*}$ T-gel sin acidificar NR & 0,092 & 0,168 & 2,7 & 6,1 \\
\hline${ }^{*}$ T-gel sin acidificar Ret & 0,076 & & & \\
\hline ** T-gel acidificando NR & 8,66 & 11,37 & 11,8 & 96,0 \\
\hline ** T-gel acidificando Ret & 2,71 & & & \\
\hline
\end{tabular}

* Proteína determinada por Bradford

** Proteína determinada por BCA

NR: no retenido

Ret : retenido

de S. bogotensis (21);en la figura 5B se presenta el perfil cromatográfico obtenido. Se encontró un pico no retenido pequeño (I) y tres picos no resueltos al eluir con tampón glicina- $\mathrm{HCl}, \mathrm{pH} 2,8$, (fracción II). A pH 7,3 se eluyó un pico muy pequeño y a $\mathrm{pH} 8,8$ no eluyó ningún pico. Por último, la elución con tampón de alta fuerza iónica $(\mathrm{pH} 6,3,1 \mathrm{M} \mathrm{NaCl})$ resultó en un pico bien definido con una alta absorbancia. Con cada fracción eluída se hizo un pool, a excepción de los tubos con valores máximos a $\mathrm{pH} 2,8$, que se recolectaron por separado. Los ensayos de detección por Dotblot mostraron la presencia de lgY en las alícuotas del pico eluido a $\mathrm{pH} 2,8$. Observando los perfiles cromatográficos con DEAE-Sephacel, se deduce que algunos de los contaminantes presentes debían tener puntos isoeléctricos similares al pl de las $\lg Y$ (22); el perfil electroforético mostró (figura 6B, carriles 4 y 5 ) que, aunque se redujeron sustancialmente los contaminantes (figura 6B, carriles 2 y 3 ) y se observan claramente las cadenas H (70 kd) y L (25 kd), la pureza fue sólo parcial.
Posteriormente se realizó una cromatografía de exclusión molecular sobre Sephacryl S-200 del extracto final deslipidado sin acidificar (2,7 $\mathrm{mg}$ de proteína). En el perfil cromatográfico se observó que la proteína eluyó prácticamente en un solo pico, en un volumen algo mayor que el Vo, sin separarse de los contaminantes detectados por PAGE-SDS (resultados no mostrados). Por ello se utilizó un soporte de Sephacryl S-500 en el que se resolvieron tres picos, y los dos primeros fueron muy pequeños. Dado que prácticamente toda la proteína del extracto se eluyó en un solo pico y que, además, éste fue asimétrico, lo cual indica heterogeneidad, como se demostró por electroforesis (figura 6A, carril 7), se puede concluir que con este soporte no se logró un fraccionamiento adecuado.

Se ensayó una cromatografía hidrofóbica sobre fenil-sefarosa 4B del extracto final deslipidado sin acidificar (3,6 mg de proteína). Se obtuvo una fracción no retenida muy pequeña (fracción I, figura $5 \mathrm{C}$ ), una fracción al eluir con agua (II) y una 
tercera fracción (III) de aspecto turbio, al pasar MeCN sobre la columna. A las fracciones I y II se les determinó la cantidad de proteína (cuadro 2); la electroforesis de II mostró como bandas predominantes las cadenas $\mathrm{H}$ y $\mathrm{L}$ de las $\lg \mathrm{Y}$, junto con una cantidad apreciable de contaminantes (figura 6A, carril 6).

Cuando se aplicó sobre el soporte tiofílico la fracción deslipidada con acidificación (11,8 mg), el perfil cromatográfico mostró una fracción no retenida considerable (figura $7 \mathrm{~A}$, fracción I); al disminuir la fuerza iónica se obtuvo un pico de $\lg \mathrm{Y}$, evidenciado por ELISA, bien definido y con
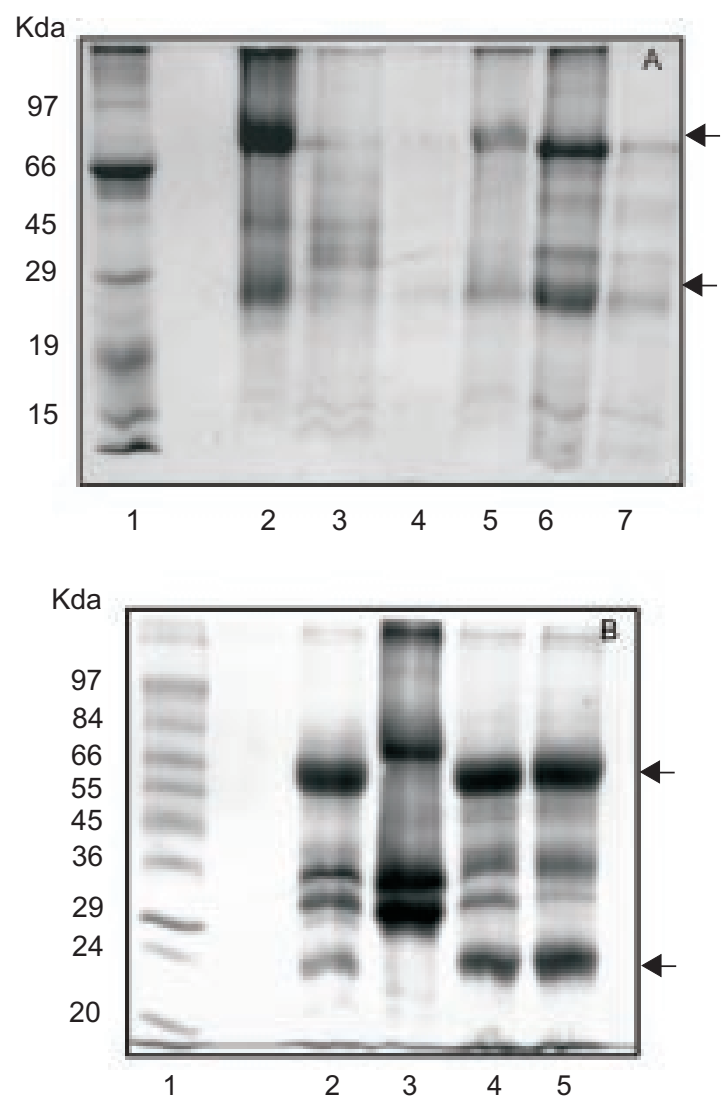

Figura 6. Análisis por PAGE-SDS de (A) fracciones de extracto sin acidificar. Carriles 1: patrones de peso molecular; 2: extracto pH 6,2; 3: fr I DEAE-Sephacel; 4: fr II DEAE-Sephacel; 5: fr III DEAE-Sephacel; 6: fr II PhenylSepharose; 7: fr III Sephacryl S-500. (B) fracciones por DEAE-Sephacel de extracto acidificado. Carriles 1: patrones

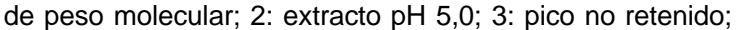
4: $\mathrm{pH} 2,8$ fracción a; 5: pH 2,8 fracción b. Las flechas indican la posición de las cadenas $\mathrm{H}$ y $\mathrm{L}$. una alta absorbancia indicadora de una buena cantidad (figura 7A, fracción II). En esta cromatografía se recuperó $90 \%$ de las IgY aplicadas, puesto que al volver a someter a cromatografía el pico I, se obtuvo un pico de $\lg Y$ bastante pequeño cuya $A b_{280}$ fue de $0,260(0,29$ $\mathrm{mg}$ ) y por Dot-blot no se detectó lgY en el pico no retenido (figura 7B, dots 5 y 7 ), aun con cantidades 6 veces mayores que las del retenido $(3,2 \mu \mathrm{g} v \mathrm{v}$. $0,5 \mu \mathrm{g}$, figura 7B, dots 5 y 6 ). Esta recuperación coincide con la observada por otros autores (29) utilizando este soporte. El extracto proveniente de la dilución con agua sin acidificar $(2,7 \mathrm{mg}$ de proteína) se corrió también sobre el soporte tiofílico, observándose un perfil muy similar (datos no mostrados) con una fracción eluída a baja fuerza iónica $(\lg Y)$ que, aunque menor que la no retenida, posee una absorbancia alta.

Con la cromatografía tiofílica se observó que a partir del extracto inicial se obtenían $\lg Y$ prácticamente puras (figura $7 \mathrm{C}$, carril 3 ) en un solo paso cromatográfico, ya que se eliminaron los contaminantes presentes en el extracto inicial (figura 7C, carriles 2 y 4) para, finalmente, obtener las $\lg Y$ con sus cadenas livianas y pesadas.

La reactividad de las $\lg Y$ obtenidas por afinidad sobre cromatografía tiofílica $(0,763 \mathrm{mg} / \mathrm{ml})$ se evaluó adicionalmente por ensayo de ELISA y Dotblot. Por Dot blot se observó reactividad hasta una dilución de 1:10000 $(1,2 \mu \mathrm{g}$ de lectina por punto) (figura 8A); los resultados muestran un reconocimiento de la lectina por parte del Ab hasta un valor límite de $0,076 \mu \mathrm{g} / \mathrm{ml}$ de anticuerpo, lo cual indica una alta sensibilidad. Por ensayo de ELISA se observó un incremento importante en la detección de lectina $(1,5 \mu \mathrm{g})$ con $10 \mu \mathrm{g}$ de anticuerpo puro $(\lg Y)$ respecto al extracto crudo (figura 8B), lo que indica que el grado de purificación del anticuerpo alcanzado con este método fue considerable. Con cantidades mayores a 12 ug de lgY pura se observó una disminución de la reacción $\mathrm{Ag}-\mathrm{Ab}$ (figura 8B).

\section{Discusión}

La respuesta inmune obtenida con la lectina de $S$. bogotensis, además de mostrar la correlación esperada entre dosis de antígeno aplicada y cantidad de inmunoglobulina producida, presentó 

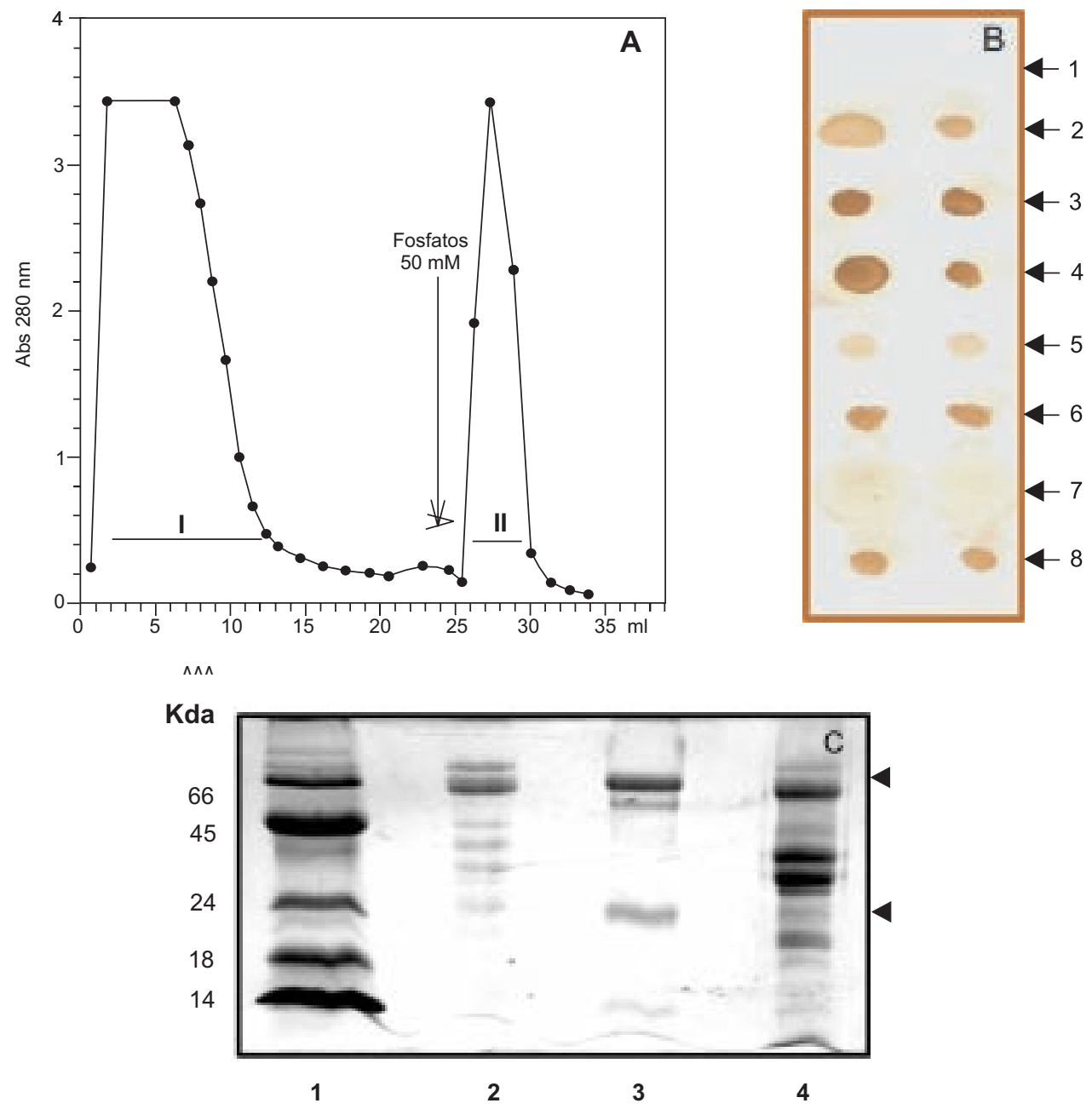

Figura 7. (A) Cromatografía tiofílica del extracto deslipidado a pH 5,0. (B) Detección de lgY por Dot blot de las fracciones no retenidas (dot 5: 3,2 $\mu \mathrm{g}$; dot 7: 1,85 $\mu \mathrm{g}$ ), retenidas (dot 3:2,7 $\mu \mathrm{g} ;$ dot 4: 3,6 $\mu \mathrm{g}$; dot 6: 0,5 $\mu \mathrm{g} ; \operatorname{dot} 8: 1,45 \mu \mathrm{g}$ ); control (1) y extracto inicial (dot 2: 4,4 $\mu \mathrm{g}$ ). (C) PAGE-SDS de las fracciones de la cromatografía tiofílica. Carriles 1: patrones de peso molecular; 2: extracto deslipidado; 3: fracción II; 4: fracción I.

una persistencia superior a 70 días, lo cual implica una cantidad considerable de material disponible para aislar las IgY. Resultados similares han sido obtenidos por Gassmann et al. (2), Jensenius y Koch (22) y Chen et al. (32).

Entre los métodos de deslipidación y extracción de IgY, la precipitación con PEG 8000 permite una buena recuperación de $\lg Y$ con pocos contaminantes; sin embargo, su remoción, necesaria para los análisis posteriores, es difícil. Se ha utilizado la precipitación de las proteínas con etanol preenfriado para separarlas del PEG en solución (12); no obstante, el carácter potencialmente denaturante del etanol puede afectar la actividad de las IgY, lo cual efectivamente se comprobó en los ensayos de actividad por ELISA.

La deslipidación por dilución con agua sin acidificar (23) es un método sencillo y rápido (extracto final en 2 a 3 días), con el cual se puede procesar un volumen apreciable de yemas, lo que permite la extracción de gran cantidad de anticuerpos en condiciones que no afectan la actividad de las IgY. El gran inconveniente que presenta es la 

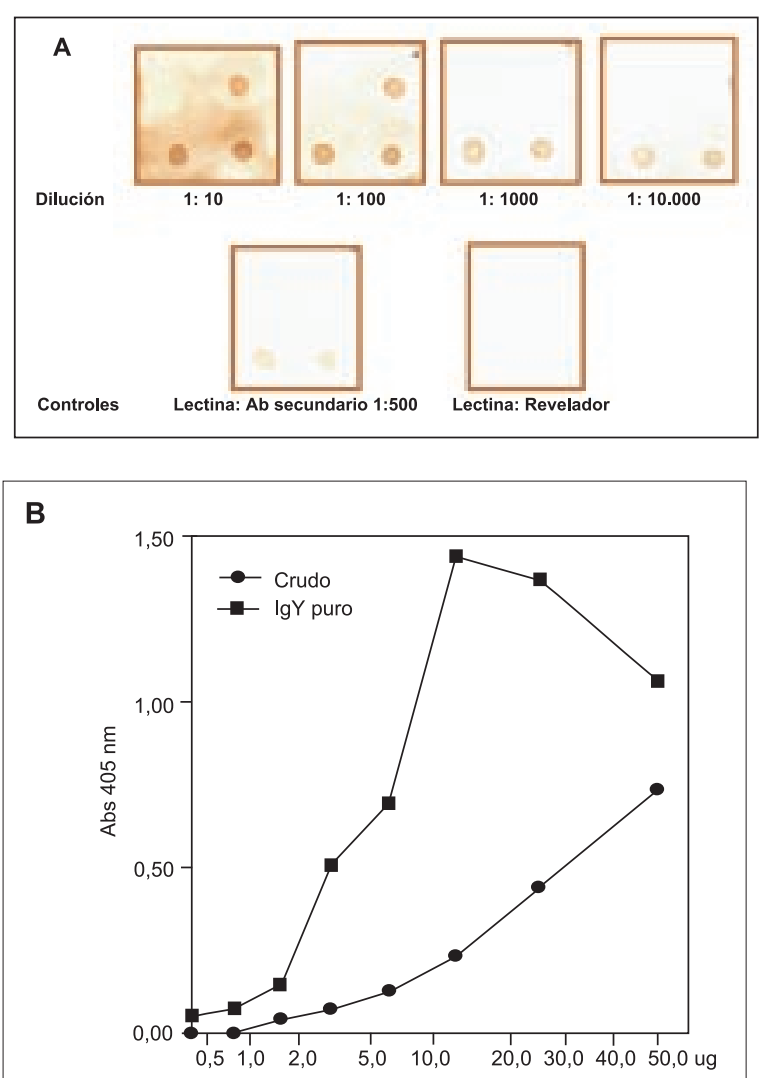

Figura 8. Detección de la interacción lectina Salvia bogotensis: IgY por (A) Dot blot con diluciones sucesivas del anticuerpo; (B) ELISA del extracto de $\lg \mathrm{Y}$ crudo y del $\lg \mathrm{Y}$ purificado por cromatografía tiofílica.

remoción incompleta de los lípidos de la yema, que pueden interferir en ensayos como la cuantificación de proteína.Teniendo en cuenta esta interferencia, y que el Coomassie G 250 no se une en igual proporción a todas las proteínas (25), es posible que la cantidad de proteínas recuperadas por este método se subestime.

Akita y Nakai (24) mostraron que el método de dilución con agua puede optimizarse acidificando la solución a pH 5,0.Nuestros resultados muestran que este método es el mejor procedimiento de delipidación y extracción pues, además de ser sencillo, preservó muy bien la actividad de las $\lg Y$, se obtuvieron las mejores recuperaciones de proteína, se eliminaron los contaminantes de alto PM y el número de proteínas contaminantes de bajo PM no fue muy elevado (4-5).
En los ensayos de purificación con DEAESephacel vale la pena resaltar el hecho de que con este tipo de cromatografía, las IgG se eluyen siempre en la fracción no retenida (27) y las altas fuerzas iónicas eluyen otras proteínas y pigmentos, mientras que las $\lg Y$ son retenidas en este soporte; probablemente las diferencias en $\mathrm{pl}$ de los dos tipos de inmunoglobulinas explican este comportamiento. La purificación incompleta que observamos corrobora los resultados de otros autores (24), quienes aseveran que con este método sólo se alcanza una pureza de $50 \%$ a $60 \%$. En consecuencia, aunque la cromatografía de intercambio aniónico es capaz de retener grandes cantidades de proteína (150 $\mathrm{mg}$ albúmina $/ \mathrm{ml}$ gel), debe acompañarse de otros métodos de purificación.

Según Hassl y Aspöck (28), al combinar la cromatografía hidrofóbica con la cromatografía sobre Sephacryl S-300 (rango de exclusión 10 a $1500 \mathrm{kDa}$ ), se obtienen anticuerpos con purezas mayores a $85 \%$. Sin embargo, nosotros observamos que combinando estos dos métodos no es posible aumentar la pureza de las $\lg Y$, aunque se utilice el Sephacryl S-500 que tiene mayor poder de resolución que el Sephacryl S300.

Según Scoble y Scopes (33), la activación del soporte con DVS debe realizarse, por lo menos, durante 8 horas para que el soporte tiofílico ( $T$ gel) llegue al nivel óptimo de retención ( $\pm 26 \mathrm{mg}$ de anticuerpo/ml de gel); los resultados con la muestra acidificada que se corrió sobre una columna activada durante 8 horas lo confirman, ya que la cantidad de anticuerpo retenida fue considerable (cuadro 2).

El análisis de los datos del cuadro 2 muestra que en varios casos sólo entre $6 \%$ y $15 \%$ de la proteína aplicada se recupera. Esto podría deberse, por una parte, a la interferencia de los lípidos residuales presentes en los extractos sin acidificar y, por otra parte, a la cuantificación por el método de Bradford, que según Hansen et al. (29) subestima la cantidad de lgY hasta en $50 \%$. Esto se corrobora por el hecho de que cuando se aplican extractos acidificados y se cuantifica por $\mathrm{BCA}$, la recuperación aumenta muchísimo, como 
en el caso de la cromatografía tiofílica de la muestra acidificada (96\%), o en la cromatografia sobre DEAE-Sephacel del extracto acidificado (53\%).

El conjunto de resultados obtenidos con los ensayos de purificación mostraron que la cromatografía tiofílica de la muestra acidificada es el mejor método, ya que permitió obtener lgY prácticamente puras con muy buenos rendimientos usando un proceso sencillo y muy reproducible, con el cual se preservó la actividad de los anticuerpos.

Los resultados globales del trabajo permiten afirmar que se establecieron los mejores procedimientos para deslipidar, extraer y obtener eficientemente $\mathrm{lg} Y \mathrm{~s}$ de muy buena calidad.

Los anticuerpos así obtenidos y purificados han demostrado ser una herramienta muy útil en estudios de reconocimiento del antígeno Tn en líneas celulares tumorales por parte de la lectina de $S$. bogotensis (21), y serán utilizados en estudios inmunohistoquímicos y de interacciones con células mediadas por la lectina.

\section{Agradecimientos}

Al veterinario Fabio Ortiz (granja avícola La Colina, Subachoque) por facilitar los animales y las instalaciones para los ensayos de inmunización.

\section{Conflicto de intereses}

En la realización de esta investigación no hubo conflicto de intereses, pues ninguna influencia económica o política incidió en sus resultados.

\section{Financiación}

Colciencias (Proyecto 1101-05-13602) y División de Investigaciones de la Universidad Nacional (Proyecto 205011003540).

\section{Referencias}

1. Akita EM, Nakai S. Production and purification of Fab' fragments from chicken egg yolk immunoglobulin $Y$ (IgY). J Immunol Methods 1993;162:155-64.

2. Gassmann $\mathbf{M}$, Thömmes $\mathbf{P}$, Weiser $\mathbf{T}$, Hübscher $\mathbf{U}$. Efficient production of chicken egg yolk antibodies against a conserved mammalian protein. FASEB $\mathrm{J}$ 1990;4:2528-32.

3. Wu C,Yang J, Zhou J, Bao S, Zou L, Zhang P et al. Production and characterisation of a novel chicken $\lg Y$ antibody raised against C-terminal peptide from human thymidine kinase I. J Immunol Methods 2003; 277:157-69.

4. Cook C, Pao W, Firca JR, Anderson BE, Fryer JP. Simple Purification Methods for an aGalactose-Specific antibody from chicken eggs. J Biosci Bioeng 2001;91: 305-10.

5. Bizhanov G, Vyshniauskis G. A comparison of three methods for extracting IgY from the egg yolk of hens immunized with Sendai virus. Vet Res Commun 2000; 24:103-13.

6. Almeida CM, Kanashiro MM, Rangel FB, Mata MFR, Kipnis TD, da Silva WD. Development of snake antivenom antibodies in chickens and their purification from yolk. Vet Rec 1998;143:579-84.

7. Narat M. Production of antibodies in chickens. Food Technol Biotechnol 2003;41:259-67.

8. Warr GW, Magor KE, Higgins DA. IgY: clues to the origins of modern antibodies. Immunol Today 1995; 16:392-8.

9. Zhang WW. The use of gene-specific IgY antibodies for drug target discovery. Drug Discov Today 2003;8: 364-71.

10. Rose ME, Orlans E, Buttres N. Immunoglobulin classes in the hen's egg: their segregation in yolk and white. Eur J Immunol 1974;4:521-3.

11. Carroll SB, Stollar BD. Antibodies to calf thymus RNA polymerase II from egg yolks of immunized hens. J Biol Chem 1983;258:24-6.

12. Polson A, Coetzer T, Krugar J, von Maltzahn E, van der Merwe KJ. Improvements in the isolation of lgY from the yolks of eggs laid by immunized hens. Immunol Invest 1985;14:323-7.

13. Larsson A, Karlsson-Parra A, Sjöquist J. Use of chicken antibodies in enzyme immunoassays to avoid interference by rheumatoid factors. Clin Chem 1991; 37:411-4.

14. Kronvall G, Seal US, Finstad J, Williams RC Jr. Phylogenetic insight into evolution of mammalian Fc fragment of $\gamma \mathrm{G}$ globulin using staphylococcal protein $A . J$ Immunol 1970;104:140-7.

15. Larsson A, Wejaker PE, Forsberg PO, Lindahl T. Chicken antibodies: a tool to avoid interference by complement activation in ELISA. J Immunol Methods 1992;156:79-83.

16. Jensenius JC, Andersen I, Hau J, Crone M, Koch C. Eggs: conveniently packaged antibodies. Methods for purification of yolk IgG. J Immunol Methods 1981; 46:63-8.

17. Dahr W, Uhlenbruck G, Bird GW. Cryptic A-like receptor sites in human erythrocyte glycoproteins: proposed nature of Tn Antigen. Vox Sang 1974;27:29-42. 
18. Berger E. Tn-Syndrome. Biochim Biophys Acta 1999; 1455:255-68.

19. Hirohashi S, Clausen H, Yamada T, Shimosato Y, Hakomori S. Blood group A cross-reacting epitope defined by monoclonal antibodies NCC Lu-35 and 81 expressed in cancer of blood group $\mathrm{O}$ or $\mathrm{b}$ individuals. Its identification as "Tn antigen". Proc Natl Acad Sci USA 1985;82:7039-43.

20. Springer GF. T and Tn, general carcinoma autoantigens. Science 1984;244:1198-206.

21. Vega N. Caracterización bioquímica, funcional y biológica de la lectina de Salvia bogotensis (tesis). Bogotá: Universidad Nacional de Colombia; 2004.

22. Jensenius JC, Koch C. Antibodies packaged in eggs. En: Johnstone AP, Turner MW, editors. Immunochemistry I: A practical approach. Oxford: IRL Press Oxford University Press; 1997.p:89-107.

23. Akita EM, Nakai S. Comparison of four purification methods for the production of immunoglobulins from eggs laid by hens immunized with an enterotoxigenic E. coli strain. J Immunol Methods 1993;160:207-14.

24. Akita EM, Nakai S. Immunoglobulins from egg yolk: Isolation and purification. J Food Sci 1992;57:62934.

25. Bradford MM. A rapid and sensitive method for the quantitation of microgram quantities of protein utilizing the principle of protein-dye binding. Anal Biochem 1976; 72:248-54.
26. Smith PK, Krohn RI, Hermanson GT, Mallia AK, Gartner FH, Provenzano MD, et al. Measurement of protein using bicinchoninic acid. Anal Biochem 1985; 150:76-85.

27. Baines G, Thorpe R. Purification of Immunoglobulin $\mathrm{G}(\lg G)$. In: Manson $M$, editor. Inmunochemical Protocols. Methods in molecular biology. Totowa New Jersey: Humana Press; 1992. p.79-103.

28. HassI A, Aspock H. Purification of egg yolk immunoglobulins. A two-step procedure using hydrophobic interaction chromatography and gel filtration. $\mathrm{J}$ Immunol Methods 1988;110:225-8.

29. Hansen P, Scoble JA, Hanson B, Hoogenraad NJ. Isolation and purification of immunoglobulins from chicken eggs using thiophilic interaction chromatography. J Immunol Methods 1998;215:1-7.

30. Hermanson GT, Mallia A, Smith P. Immobilized affinity ligand techniques. San Diego: Academic Press; 1992. p.110-6.

31. Laemmli UK. Cleavage of structural proteins during the assembly of the head of bacteriophage T4. Nature 1970;227:680-5.

32. Chen CC, Tu YY, Chen TL, Chang HM. Isolation and characterization of immunoglobulin in yolk (IgY) specific against hen egg white Lysozyme by immunoaffinity chromatography. J Agr Food Chem 2002;50:5424-8.

33. Scoble JA, Scopes RK. Ligand structure of the divinylsulfone-based T-gel. J Chromatogr A 1997;787: 47-54. 